\title{
PHYSIOLOGICAL CHARACTERISTICS OF THE SOCKS MADE FROM BAMBOO AND CONVENTIONAL FIBERS
}

Dušan S. Trajković1 ${ }^{\star}$, Predrag S. Tasić2, Jovan M. Stepanović ${ }^{1}$, Tatjana I. Šarac ${ }^{1}$, Nataša M. Radmanovac ${ }^{1}$

1 University of Niš, Faculty of Technology, Leskovac, Serbia

2Dunav AD, Grocka, Serbia

In this work, physiological characteristics of the socks made from yarns with similar physical and mechanical properties but of different raw materials (100\% bamboo fibers, $100 \%$ cotton fibers, $100 \%$ viscose, and blend with ratio $60 \%$ cotton/40 \% PES) were investigated.

The socks were knit with plain right-left 1:1 stitch and a ribbed 3:1 right-left stitch. In both stitches, the socks made from the bamboo yarn showed much better thermo-physiological characteristics compared to those made from conventional fiber yarns. Because of micro-cracks in the structure of fibers, the knitwear made from bamboo yarn has much better moisture absorption and at the same time the excellent ventilation and keeps the warmth. This contributes to the feeling of freshness and relaxation and has a particularly good effect of cooling in the summer.

All this suggests that in the future, due to its properties, the bamboo fiber and yarn made from it will be increasingly used in the textile industry.
(ORIGINAL SCIENTIFIC PAPER) UDK 677.072:687.254.8

Keywords: physiological characteristics, bamboo fibers, socks, knitwear.

\section{Introduction}

In addition to functional aspects of clothing, such as insulation and protection, clothing also has a cultural aspect, which is sometimes counterproductive in relation to the first aspect. Also, when the function of clothing is not only to protect against the heat and cold, as is the case of special purpose clothing, there may arise a conflict between the protective function of clothing and the thermal function of the body, which causes discomfort of physical exertion, and in extreme cases, there may be a risk of an injury or illness due to the heat or cold. Therefore, the regulation of the body temperature and the heat exchange between the body and the environment is a very important process [1].

One of the most important aspects of clothing is comfort. The properties such as thermal resistance, air permeability, or water vapor permeability, are important for thermal comfort of clothing. Clothing comfort plays a key role in its selection. It is believed that a product is evaluated precisely on the basis of these qualities. Clothing comfort depends on several factors, one of which is thermal comfort. Other factors influencing the comfort of clothing include softness, elasticity, moisture expansion, and others. It should be noted that yarn properties, such as thermal resistance, thermal conductivity and heat retention depend on knitwear characteristics, such as the structure, density, moisture content, type and properties of the fibers, the way of knitting, finishing, compressibility, air permeability, and the ambient temperature. Thus, the thermal comfort of knitwear really depends on the type of yarn or fibers and their properties. The type of fiber, spinning technology, mass per unit length, number of twists, hairiness of the yarn, knitwear thickness and porosity and finishing are the main factors that determine the performance and comfort of the knitwear [2].

Water vapor permeability is a very important feature of the knitwear, especially for the knitwear worn under the conditions with the energy is spent which causes sweating. During certain activities, the human body is cooled by the evaporation of sweat, so the knitwear must have the ability to remove the moisture in order to preserve comfort and reduce the heat loss due to moisture. In addition to the above properties, the ability of a material to prevent or allow the passage of the air depends on the thickness, porosity, design, structure and geometry of the knitwear [3].

Based on the properties they own, bamboo fiber yarns are characterized by an exceptional ability to breathe and the ability to maintain freshness. Scanning electron microscopy (SEM) of bamboo fibers revealed the internal structure of the bamboo fiber cross section, where it was found that the bamboo fiber is filled with countless micro-gaps and micro-cracks which contributes to better

\footnotetext{
*Author address: Dušan Trajković, Faculty of Technology, 16000 Leskovac, Bulevar oslobođenja 124, Serbia

E-mail: dusan@tf.ni.ac.rs

The manuscript received: April, 22, 2014.

Paper accepted: May, 28, 2014.
} 
moisture absorption by the fibers and improves the ventilation $[4,5,6,7,8]$.

The main objective of this study was to investigate whether the thermo-physiological properties of the knitwear made from bamboo yarn differ significantly from the conventional knitwear made from natural and regenerated cellulose yarn.

In addition to the tests of structural characteristics of the used yarn, the air permeability, water vapor permeability and resistance to pilling tests were also carried out.

\section{Experimental}

In the experimental part, bamboo yarn was used with longitudinal mass 28.18 tex ( $\mathrm{Nm} 35.48 / 1)$ supplied by
"China Bamboo Textile Co." from China, combed cotton yarn with longitudinal mass 30.28 tex (Nm 33.02/1) supplied by "Spentex", India, viscose yarn with longitudinal mass 28.78 tex (Nm 34.74/1) and combed yarn, a blend of $60 \%$ cotton and $40 \%$ PES with longitudinal mass 28.70 tex (Nm 34.84/1).

The testing of the properties of these yarns was carried out according to standardized laboratory methods. They define the usefulness of the socks produced on Lonati machine from Italy, the most modern hosiery machines. The results of these tests are shown in Table 1.

Table 1. Characteristics of yarns used in the sock production process

\begin{tabular}{|c|c|c|c|c|c|c|c|}
\hline \multirow[b]{2}{*}{ Item } & \multirow[b]{2}{*}{ Testing elements } & \multirow{2}{*}{$\begin{array}{l}\text { Unit of } \\
\text { measure }\end{array}$} & \multirow{2}{*}{$\begin{array}{l}\text { Testing } \\
\text { method }\end{array}$} & \multicolumn{4}{|c|}{ Obtained values } \\
\hline & & & & $\begin{array}{c}\text { Sample } 1 \\
100 \% \\
\text { Bamboo }\end{array}$ & $\begin{array}{c}\text { Sample } 2 \\
100 \% \\
\text { Cotton }\end{array}$ & $\begin{array}{c}\text { Sample } 3 \\
100 \% \\
\text { Viscose }\end{array}$ & $\begin{array}{c}\text { Sample } 4 \\
60 \% \text { Cotton, } \\
40 \% \text { PES }\end{array}$ \\
\hline \multirow[t]{2}{*}{1.} & \multirow{2}{*}{$\begin{array}{l}\text { Yarn longitudinal } \\
\text { mass }\end{array}$} & $\mathrm{Nm}$ & $\begin{array}{c}\text { SRPS } \\
\text { ISO }\end{array}$ & $35,48 / 1$ & $33.02 / 1$ & $34.74 / 1$ & $34.84 / 1$ \\
\hline & & tex & 2060 & $28.18 \times 1$ & $30.28 \times 1$ & $28.78 \times 1$ & $28.70 \times 1$ \\
\hline \multirow{3}{*}{2.} & \multirow{3}{*}{$\begin{array}{l}\text { Yarn breaking force } \\
\text { - Variation coefficient }\end{array}$} & $\mathrm{cN}$ & & 469.0 & 461.0 & 450.0 & 399.0 \\
\hline & & $\mathrm{cN} \cdot \operatorname{tex}^{-1}$ & ISO & 16.64 & 15.22 & 15.63 & 13.90 \\
\hline & & $\%$ & 2002 & 5.08 & 6.74 & 4.57 & 2.0 \\
\hline \multirow[t]{2}{*}{3.} & $\begin{array}{l}\text { Elongation at break } \\
\text { - average value }\end{array}$ & $\%$ & $\begin{array}{l}\text { SRPS } \\
\text { ISO }\end{array}$ & 15.06 & 4.72 & 13.12 & 3.93 \\
\hline & - variation coefficient & $\%$ & 2062 & 5.15 & 6.22 & 9.27 & 3.49 \\
\hline \multirow[t]{2}{*}{4.} & Yarn twist & $m^{-1}$ & $\begin{array}{c}\text { SRPS } \\
\text { F.S2.05 }\end{array}$ & 601.4 & 633.8 & 610.0 & 615.0 \\
\hline & - twist direction & & 1 & „Z“ & „Z“ & \#光 & „Z“ \\
\hline
\end{tabular}

The examination of the longitudinal yarn mass was conducted on an Uster apparatus in accordance with SRPS ISO 2060 standard, while the twist number was tested on a Torsiometer in accordance with SRPS ISO 2061 standard.

Also, comparative tests of the breaking force and yarn elongation were carried out on a "Kovstan" dynamometer with software, in accordance with SRPS ISO 2062:2002 standards.

A comparison of the values given in Table 1 for bamboo yarns and other tested yarns shows that the bamboo yarn has three times greater elongation than the cotton yarn, which is one of the important characteristics of the bamboo fiber yarn, that is, it has great elasticity. Only viscose yarn has lower, but similar elongation, and this originates from the fact that bamboo yarn is obtained by the same procedure as viscose yarn, and belongs to the same group of regenerated cellulose fibers, from which the later mentioned yarn is produced.

Other test methods used in this investigation worth mentioning are:

- $\quad$ Examination of the number of loops horizontally and vertically (knitting density), standard ISO 7211/2

- Examination of the loop length, standard EN 14970: 2006;

- $\quad$ Air permeability test, standard EN ISO 9237;

- Water vapor permeability test, standard ASTM E 96-95;

- $\quad$ Resistance to pilling test, ASTM standard 3514.

In the sock production plant, four types of yarns were used to produce two types of socks which were knit with a plain stitch, Figure 1, and a ribbed stitch, Figure 2. 


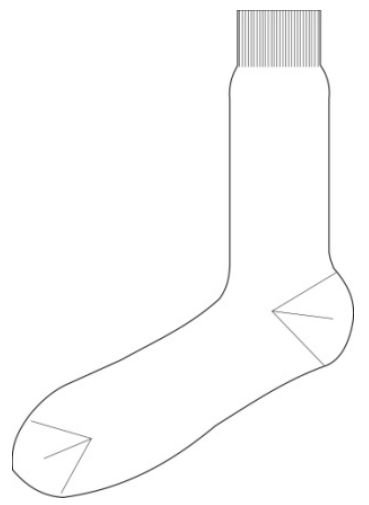

Figure 1. Plain stitch sock

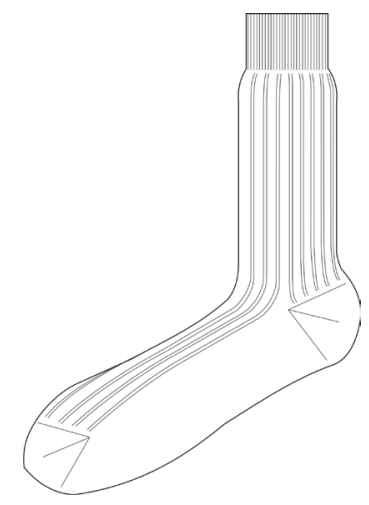

Figure 2. Ribbed stitch sock
Two types of socks were knit with a plain stitch (rightleft stitch) on a single-cylinder Lonati GOAL 462 machine, measuring 3"3/4 with 168 pins and a ribbed stitch (right-left stitch 3:1) on a double cylinder machine Lonati BRAVO 856, measuring 3"3/4 with 168 needles in three different colors, navy, grey and black, to produce a large number of samples and thus obtain reliable test results.

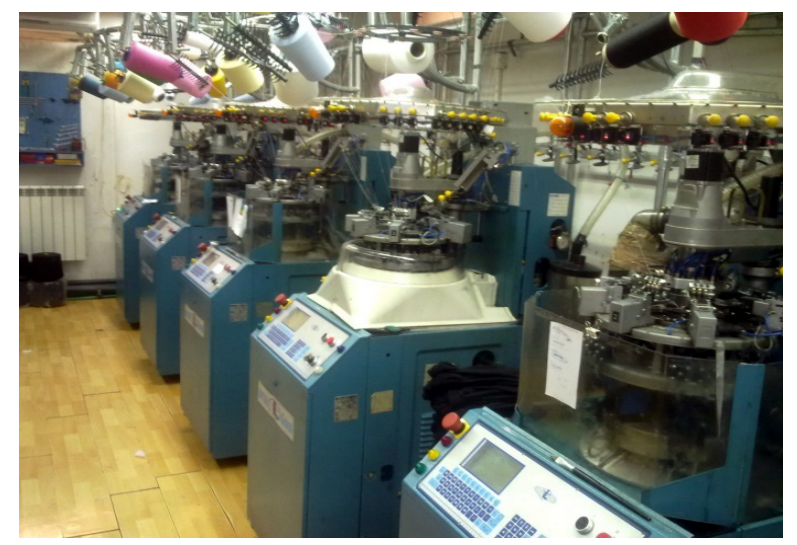

Figure 3. The sock production plant where the samples were made

In addition to these yarns, used in making socks, which in our case represent a variable parameter, poly- amide filament fineness $44 \times 2$ PA 6.6 and covered rubber thread in the initial elastic part, the so-called render, with fineness 90 were used as the invariable parameter.

The sock production was done at the facility with a relative humidity of $65 \% \pm 2 \%$ at $25^{\circ} \mathrm{C} \pm 2$. The prepared samples were left for 24 hours to relax and absorb some humidity, after that the socks were taken to the sewing machine where the front portion was seamed and the dimensions fixed by boarding machine. The testing of finished socks was done according to the above standards.

\section{Results and Discussion}

The following tests were carried out on the prepared sock samples:

Structural characteristics of the knitwear:

Loop density per $10 \mathrm{~cm}$, i.e., number of loops per width $\left(D_{h}\right)$, number of courses pre length $\left(D_{v}\right)$, and total density (D),

Length of yarn per loop (I),

Knitwear thickness (h), and

Surface mass (m).

All tests were done in accordance with ISO standards.

From the obtained values, the covering factor, TF, can be calculated:

$$
T F=\frac{\sqrt{T t}}{I}\left[\operatorname{tex}^{1 / 2} \cdot \mathrm{cm}^{-1}\right] .
$$

where $T t$ is the yarn fineness (tex),

$l$ is the length of the yarn in the loop (cm).

The following formula can express the knitwear porosity (\%):

$$
P=\left(1-\frac{m}{\rho \cdot h}\right) \cdot 100[\%] \text {. }
$$

where $\mathrm{m}$ is the surface mass $\left(\mathrm{g} \cdot \mathrm{cm}^{-2}\right)$,

$\rho$ is the fiber density $\left(\mathrm{g}^{\cdot} \mathrm{cm}^{-3}\right)$, and

$h$ is the knitwear thickness (cm).

Owing to the structural similarity (fineness, or linear density of the yarn, number of twists) of the yarn given in Table 1, knit socks were also compared with respect to the basic design characteristics. Socks of different types of yarn with plain stitch are shown in Table 2, and socks with ribbed stitch are given in Table 3.

Table 2. Structural characteristics of the plain stitch sock knitwear

\begin{tabular}{ccccccccccc}
\hline $\begin{array}{c}\text { Sample } \\
\text { No. }\end{array}$ & $\begin{array}{c}\text { Yarn used for } \\
\text { sock } \\
\text { fabrication }\end{array}$ & $\begin{array}{c}\mathrm{D}_{\mathrm{h}} \\
\left(\mathrm{cm}^{-1}\right)\end{array}$ & $\begin{array}{c}\mathrm{D}_{\mathrm{v}} \\
\left(\mathrm{cm}^{-1}\right)\end{array}$ & $\begin{array}{c}\mathrm{c} \\
\left(\mathrm{D}_{\mathrm{h}} / \mathrm{D}_{\mathrm{v}}\right)\end{array}$ & $\begin{array}{c}\mathrm{D} \\
\left(\mathrm{cm}^{-2}\right)\end{array}$ & $\begin{array}{c}\mathrm{h} \\
(\mathrm{mm})\end{array}$ & $\begin{array}{c}\mathrm{m} \\
\left(\mathrm{g} \cdot \mathrm{m}^{-2}\right)\end{array}$ & $\begin{array}{c}\mathrm{I} \\
(\mathrm{mm})\end{array}$ & $\begin{array}{c}\mathrm{TF} \\
\left(\mathrm{tex}^{1 / 2} \cdot \mathrm{cm}^{-1}\right)\end{array}$ & $\begin{array}{c}\mathrm{P} \\
(\%)\end{array}$ \\
\hline 1 & $100 \%$ bamboo & 10.5 & 12.0 & 0.87 & 126 & 1.2 & 318,8 & 4.7 & 11.29 & 98.25 \\
2 & $100 \%$ cotton & 10.0 & 13.0 & 0.77 & 130 & 1.1 & 262,8 & 4.7 & 11.70 & 98.45 \\
3 & $\begin{array}{c}100 \% \text { viscose } \\
4\end{array}$ & 10.8 & 12.0 & 0.9 & 129.6 & 1.05 & 284,0 & 4.7 & 11.41 & 98.22 \\
4 & $\begin{array}{c}60 \% \text { cotton/ } \\
40 \% \text { PES }\end{array}$ & 10.0 & 11.5 & 0.87 & 115 & 1.0 & 247,5 & 4.7 & 11.39 & 98.33 \\
\hline
\end{tabular}


Table 3. Structural characteristics of the ribbed stitch sock knitwear

\begin{tabular}{ccccccccccc}
\hline $\begin{array}{c}\text { Sample } \\
\text { No. }\end{array}$ & $\begin{array}{c}\text { Yarn used for } \\
\text { sock } \\
\text { fabrication }\end{array}$ & $\begin{array}{c}\mathrm{D}_{\mathrm{h}} \\
\left(\mathrm{cm}^{-1}\right)\end{array}$ & $\begin{array}{c}\mathrm{D}_{\mathrm{v}} \\
\left(\mathrm{cm}^{-1}\right)\end{array}$ & $\begin{array}{c}\mathrm{c} \\
\left(\mathrm{D}_{\mathrm{h}} / \mathrm{D}_{\mathrm{v}}\right)\end{array}$ & $\begin{array}{c}\mathrm{D} \\
\left(\mathrm{cm}^{-2}\right)\end{array}$ & $\begin{array}{c}\mathrm{h} \\
(\mathrm{mm})\end{array}$ & $\begin{array}{c}\mathrm{m} \\
\left(\mathrm{g} \cdot \mathrm{m}^{-2}\right)\end{array}$ & $\begin{array}{c}\mathrm{I} \\
(\mathrm{mm})\end{array}$ & $\begin{array}{c}\mathrm{TF} \\
\left(\mathrm{tex}^{1 / 2} \cdot \mathrm{cm}^{-1}\right)\end{array}$ & $\begin{array}{c}\mathrm{P} \\
(\%)\end{array}$ \\
\hline 1 & $100 \%$ bamboo & 10.0 & 15.0 & 0.66 & 150 & 1.4 & 238 & 5.1 & 10.40 & 98.88 \\
2 & $100 \%$ cotton & 9.2 & 14.0 & 0.65 & 128.8 & 1.6 & 246 & 5.1 & 10.78 & 99.01 \\
3 & $\begin{array}{c}100 \% \text { viscose } \\
4\end{array}$ & 11.0 & 14.0 & 0.78 & 154 & 1.3 & 209 & 5.1 & 10.51 & 98.94 \\
\hline & $\begin{array}{c}60 \% \text { cotton/ } \\
40 \% \text { PES }\end{array}$ & 10.0 & 13.0 & 0.77 & 130 & 1.6 & 242 & 5.1 & 10.50 & 98.97 \\
\hline
\end{tabular}

In Table 2 and $3 D_{h}$ - number of loops per width; Dv - number of courses per length; c - density coefficient; D - total density; h - knitwear thickness; $\mathrm{m}$ - surface mass; I - length of yarn per loop; TF - covering coefficient; P - knitwear porosity.

The thermo-physiological behavior of knitwear is influenced by bulk density, porosity, air permeability and water vapor permeability. Bulk density of the knitwear, $\delta\left(\mathrm{g}^{\circ} \mathrm{cm}^{-3}\right)$, is defined as the quotient of the surface density and thickness of the knitwear. The porosity of the knitwear, $\mathrm{P}(\%)$, is defined as open spaces between the yarns and within the yarn. Considering that the yarn was obtained by conventional (ring) spinning which allows the compact structure of the core and, to a lesser or greater extent, the fibrous structure, we obtain lower values for the porosity of the socks with plain stitch compared to the socks with a ribbed structure, as it can be seen from Tables 2 and 3.

Air permeability was assessed according to SRPS EN ISO 9237 standard on a CARL SCHROEDER-L-14 apparatus, after the samples had been conditioned to standard requirements. In our case, the studied area was $10 \mathrm{~cm}^{2}$. The sample of the given size was placed on the ring and tightened. The suction fan mounted on the sample produced under-pressure of $0-20 \mathrm{mbar}\left(0-2 \times 10^{3} \mathrm{kPa}\right)$. A regulator controls the constant pressure of the air that passes through the knitwear. Airflow meter works on the principle of a float calibrated at $20^{\circ} \mathrm{C}$ and $760 \mathrm{~mm}$ of the water column. It measures the flow rate of air per minute and the values are read directly on the scale.

Air permeability of the knitwear is defined as the volume of air in cubic meters per minute passing through a square meter of the knitwear at a constant pressure $\left(\mathrm{m}^{3} \cdot \mathrm{m}^{-2} \cdot \mathrm{min}^{-1}\right)[9,10,11,12]$.

Table 4. Physical properties of the plain stitch sock knitwear

\begin{tabular}{cccccc}
\hline $\begin{array}{c}\text { Sample } \\
\text { No. }\end{array}$ & $\begin{array}{c}\text { Yarn used for sock } \\
\text { fabrication }\end{array}$ & $\begin{array}{c}\text { Bulk density } \\
\text { of the } \\
\mathrm{knitwear} \\
\left(\mathrm{g} \cdot \mathrm{cm}^{-3}\right)\end{array}$ & $\begin{array}{c}\text { Air } \\
\text { permeability } \\
\left(\mathrm{m}^{3} \cdot \mathrm{m}^{-2} \cdot \mathrm{min}^{-1}\right)\end{array}$ & $\begin{array}{c}\text { Water vapor } \\
\text { permeability } \\
\left(\mathrm{g} \cdot \mathrm{m}^{-2}\right) \text { for } 24^{\mathrm{h}}\end{array}$ & $\begin{array}{c}\text { Resistance to } \\
\text { pilling }\end{array}$ \\
\hline 1 & $100 \%$ bamboo & 0.265 & 23.7 & 11.213 & 4 \\
2 & $100 \%$ cotton & 0.2389 & 27.3 & 9.432 & 3 \\
3 & $100 \%$ viscose & 0.270 & 26.4 & 9.80 & 4 \\
4 & $60 \%$ cotton/40\% PES & 0.2475 & 32.6 & 10.193 & 4 \\
\hline
\end{tabular}

Table 5. Physical properties of ribbed stitch sock knitwear

\begin{tabular}{cccccc}
\hline $\begin{array}{c}\text { Sample } \\
\text { No. }\end{array}$ & $\begin{array}{c}\text { Yarn used for sock } \\
\text { fabrication }\end{array}$ & $\begin{array}{c}\text { Bulk density } \\
\text { of the } \\
\mathrm{knitwear} \\
\left(\mathrm{g} \cdot \mathrm{cm}^{-3}\right)\end{array}$ & $\begin{array}{c}\text { Air permeability } \\
\left(\mathrm{m}^{3} \cdot \mathrm{m}^{-2} \cdot \mathrm{min}^{-1}\right)\end{array}$ & $\begin{array}{c}\text { Water vapor } \\
\text { permeability } \\
\left(\mathrm{g} \cdot \mathrm{m}^{-2}\right) \text { for } 24^{\mathrm{h}}\end{array}$ & $\begin{array}{c}\text { Resistance to } \\
\text { pilling }\end{array}$ \\
\hline 1 & $100 \%$ bamboo & 0.170 & 89 & 11.910 & 4 \\
2 & $100 \%$ cotton & 0.1537 & 106 & 10.193 & 4 \\
3 & $100 \%$ viscose & 0.160 & 132 & 10.195 & 4 \\
4 & $60 \%$ cotton/40\% PES & 0.1512 & 109 & 11.102 & 4 \\
\hline
\end{tabular}


From Tables 4 and 5 it can be seen that the values for physical properties (bulk density, air permeability, water vapor permeability and resistance to pilling) differ for socks with plain and ribbed stitches.

It is believed that the flow of air occurs in the space between the yarns affecting air permeability. Almost the entire flow occurs through the pores in the yarn; therefore, the structure of the knitwear has an important impact on the air permeability. In our case, the plain socks have a more compact and tight structure compared to the ribbed stitch socks, where the porosity within the yarn is greater and depends not only on the type of the yarn used, but also on the structure of the knitwear. Based on the test results for plain and ribbed socks, air permeability was lowest in the socks made from bamboo fibers, which proves the influence of micro-cracks within the fiber which take over the air that passes through the knitwear. All this confirms the superiority of the bamboo fiber yarn that is rightly called a hollow fiber.

The socks with the plain stitch made from the yarn blend of $60 \%$ cotton and $40 \%$ PES have the highest value for air permeability. The compact structure of the plain stitch can be explained by the presence of PES fibers in the yarn in the amount of $40 \%$.

The obtained values of air permeability of the viscose yarn used in the production of socks with plain stitch were in the same range as those obtained for the $100 \%$ cotton yarn.

The ribbed stitch socks made from the viscose yarn show the highest value for air permeability, which is mostly influenced by the structure of knitwear. The 3:1 ribbed stitch and pure viscose fibers show the best results.

The results of air permeability of the socks with plain stitch given in Table 4 are shown graphically in Figure 4 , and the results of air permeability of the socks with ribbed stitch given in Table 5 are shown graphically in Figure 5.

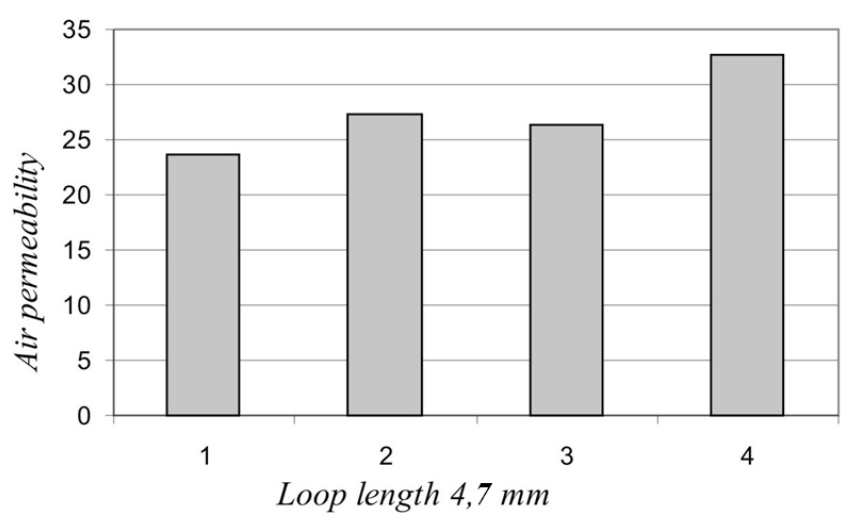

Figure 4. Air permeability in socks with plain stitch, $\left(\mathrm{m}^{3} \cdot \mathrm{m}^{-2} \cdot \mathrm{min}^{-1}\right)$

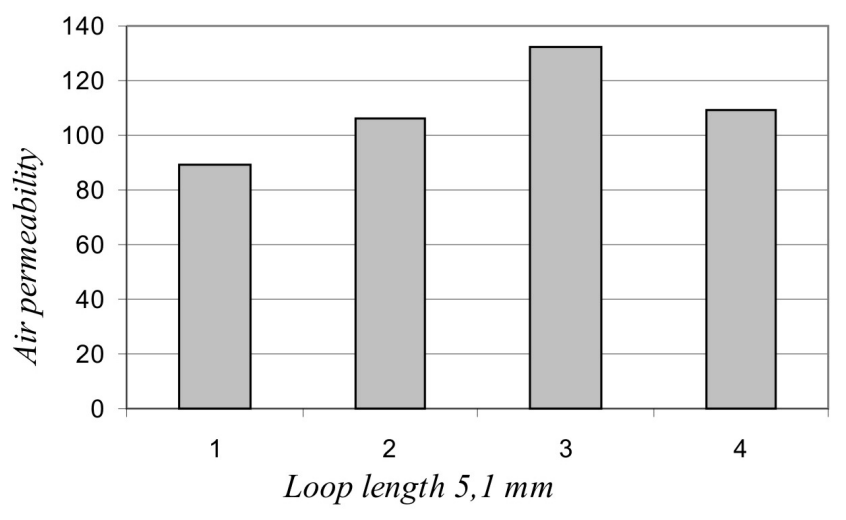

Figure 5. Air permeability in socks with ribbed stitch, $\left(\mathrm{m}^{3} \cdot \mathrm{m}^{-2} \cdot \mathrm{min}^{-1}\right)$

Comparing the diagrams of air permeability of the plain stitch socks with those of the ribbed stitch socks we see that due to the structure of the ribbed knitwear, the socks with a ribbed stitch have a greater length of the loop, resulting in a 3.5 times greater air permeability, which is manifested in the same manner in all sock samples. It is very important that the lowest value for air permeability obtained was just in the socks made from the bamboo yarn.

As for the air permeability of the socks with plain and ribbed stitches, it can be concluded that it depends on the covering coefficient, linear module of the loop and length of yarn in the loop, which is higher in socks with the ribbed stitch because of the structure of the sock.

The increase of the covering coefficient reduces the permeability of the knitwear. With the very structure of the ribbed knitwear and the method of making loops on two-cylinder machines, where there is dragging of the loops with the upper and lower cylinders, the bigger loops and the knitwear opening are obtained, thus increasing the free space for greater airflow [13].

The water vapor permeability of the knitwear is defined as the amount of vapor in grams passing for 24 hours through a square meter of the knitwear at the constant pressure $\left(\mathrm{g} \cdot \mathrm{m}^{-2} / 24 \mathrm{~h}\right)$ [14].

The water vapor permeability was investigated in three different shades of navy blue socks, grey and black, and for the plain and ribbed stitches. The test was performed by placing the knitwear samples above a glass of water at the temperature of $50^{\circ} \mathrm{C}$, so that the water level was $35 \mathrm{~cm}$ below the upper edge of the glass. After 24 hours, the change of the sample mass and the level of the water in the glass were measured, and this defined the water vapor permeability.

The results of the water vapor permeability for the socks with a plain stitch are shown graphically in Figure 6 , and those for the socks with a ribbed stitch in Figure 7. 


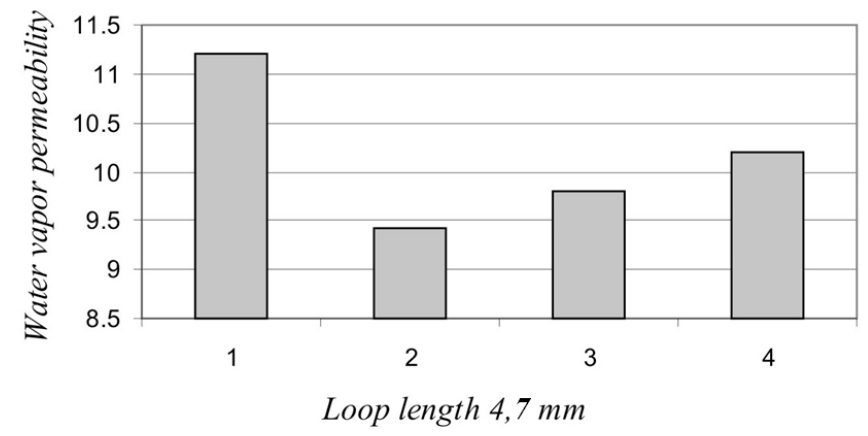

Figure 6. Water vapor permeability in plain stitch socks, $\left(\mathrm{g} \cdot \mathrm{m}^{-2}\right)$ for $24 \mathrm{~h}$

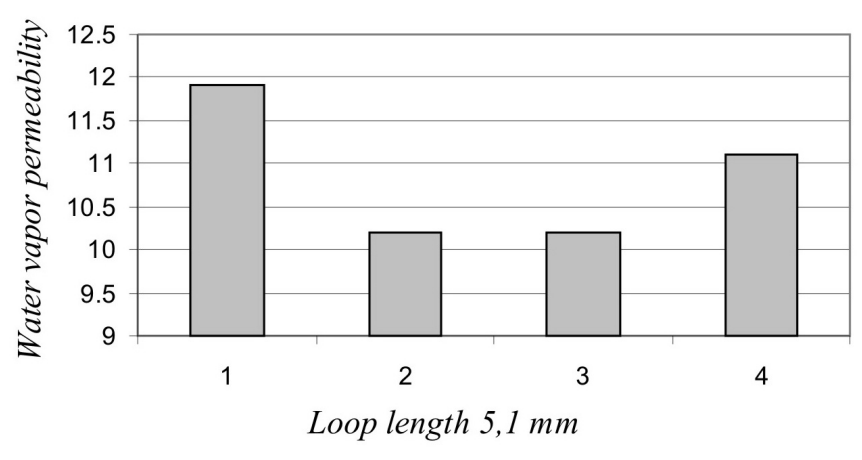

Figure 7. Water vapor permeability in ribbed stitch socks, $\left(\mathrm{g} \cdot \mathrm{m}^{-2}\right)$ for $24 \mathrm{~h}$

A comparative study of the diagrams of the water vapor permeability of the socks with a plain stitch and the diagrams for the socks with a ribbed stitch, shows that the loop length has a negligible effect on the results of the water vapor permeability. In both cases, the highest value for the water vapor permeability was obtained with the socks made from the bamboo yarn compared to other types of the yarn.

The socks made from the yarn blend $60 \%$ cotton and $40 \%$ PES have the closest results to those obtained for the plain stitch socks made from the bamboo yarn. The socks with the ribbed stitch have the water vapor permeability similar to the socks made from the yarn blends $60 \%$ cotton and $40 \%$ PES, but the highest value of the water vapor permeability was obtained for the socks made from the bamboo yarn.

The test of resistance to pilling was done on the device ICI Pilling Box Tester, which has the form of a cube. It consists of a rotating wooden box lined with cork where the samples are tumbled, and the extent to which the knitwear is resistant to pilling is determined by examination. The obtained results show that the plain stitch socks made from the bamboo yarn, viscose yarns and $60 \%$ cotton and 40 \% PES blend yarn showed grade 4, which is very good for this type of knitwear and for its use and purpose. Plain stitch socks made from cotton yarn showed the lowest value in this case, grade 3 .
In the resistance to the pilling test, the socks with a ribbed stitch made from all types of yarns had grade 4 . It can be said that the bamboo yarn, in both cases, showed excellent results, compared to other investigated yarns.

The obtained values confirm the excellent quality of the socks made from the bamboo yarn, which guarantees a long time of exploitation.

\section{Conclusion}

Owing to the similarity of the structure of the bamboo yarn with other yarns used (yarn count, density, number of twists), a comparison of knitwear (plain and ribbed stitch) produced from conventional natural yarns and regenerated cellulose yarns, the conclusion is that the socks made from the bamboo yarn showed excellent results. Most notably, the results obtained in testing the air permeability and the results in testing the water vapor permeability should be emphasized.

It can be concluded that in future, the bamboo yarn will become more prevalent in the textile industry thanks to the properties in its possession.

The bamboo yarn has some extraordinary properties: It is the healthiest natural material for the skin!

Bamboo grows under natural organic conditions - without pesticides or fertilizers, unlike ordinary cotton, for the cultivation of which $25 \%$ of the total amount of pesticides in the world is used.

Bamboo fiber is hypoallergenic - perfect for extremely sensitive baby skin.

Clothing made from the bamboo fiber yarn has thermoregulatory effects - it helps maintain the body temperature, which is of particular importance for small babies.

Eco-friendly - one of the most important qualities when it comes to the bamboo fiber is the fact that bamboo absorbs $35 \%$ more carbon dioxide than trees! More bamboo in the nature contributes to the reduction of the level of $\mathrm{CO}_{2}$ on a global level, and therefore significantly helps the fight against global warming. Bamboo helps prevent soil erosion because it absorbs more water than other plants. Bamboo belongs to the grass species, so it can regenerate and no human labor is necessary for its cultivation.

Due to the specific structure of bamboo, the knitwear has excellent ventilation and keeps the warmth. This contributes to the feeling of freshness and relaxation, and has a particularly good effect of cooling in the summer.

- Bamboo fibers contain pectin, which has a calming, refreshing and nourishing effect on skin cells. In addition, it acts as an antibacterial and natural deodorant agent. The tests have shown that these effects are preserved even after numerous washings, and that the number of bacteria is reduced by more than $70 \%$. Also, bamboo fibers are healthier than the fabrics treated with chemicals, which are often the main causes of allergies in children and adults. 
Bamboo fibers absorb moisture exceptionally well - they absorb about $32 \%$ of moisture in relation to their weight, compared with $8 \%$ for cotton, or $12 \%$ for viscose.

Having in mind the results of this study it can be concluded that the bamboo yarn has a great potential in the future.

\section{Acknowledgments}

The work is part of the research project "The Development of New and the Improvement of the Existing Technological Processes for the Production of Technical Textiles" No. TR 34020, funded by the Ministry of Education and Science of the Republic of Serbia

\section{References}

[1] George Havenith, The Interaction of Clothing and Thermoregulation, Exog Dermatol 2002;1:221-230 (DOI: 10.1159/000068802).

[2] Li, Y. The Science of clothing comfort. Textile Progress 2001, 31(1/2), 1-135.

[3] Joneda, M., Kawabata, S., A Theoretical consideration on the Objective measurement of Fabric Warm/ool feeling, Objective specification of Fabric Quality, mechanical properties and performance, edied S. Kawabata et al., The Textile Machinery Society in Japan (1982).

[4] Shanghai tenbro bamboo textile co. Ltd. [online] available: http://www.Tenbro.com/en/green02.asp. Accessed 28
March 2007.

[5] Cao Taijun and Liu Gangyi, Development of Textiles Made from Bamboo Fiber and its Prospect, J. Hunan Liberal Art Sci.College (Natural Sci. Ed.), 17, 1 (2005) 57-59.

[6] Prakash Chidambaram, The Effect Of Loop Length And Yarn Linear Density On The Thermal Properties Of Bamboo Knitted Fabric (Autex Research Journal, Vol 11, NO4, December 2011).

[7] R. Čunko, Ispitivanje tekstila, Sveučilišna naklada, Zagreb, 221, (1988).

[8] Wang Yueping, New Uses of Bamboo in Textile Industry, Bull. Bamboo Rattan World, 4 (2005) 54-60.

[9] Majumdar, A.; Mukhopadhyay, S.; Yadav, R. Thermal properties of knitted fabrics made from cotton and regenerated bamboo cellulosic fibres. International Journal of Thermal Science 2010, 40(10), 2042-2048.

[10] Adine Gericke and Jani van der Pol, A comparative study of regenerated bamboo, cotton and viscose rayon fabrics. Part 1: selected comfort properties (Journal of family Ekology and Consumer, Vol 38, 2010).

[11] Snežana Stanković, Thermal properties of textile fabrics made from natural and regenerated cellulose fibers, Polymer testing 27 (2008) 41-48.

[12] Tang Rencheng, Yang Xuhong, Wang Huajie, et al., Structures and Thermal Properties of Bamboo Fiber for Textiles, Chem. Industry Forest Products, 24, 1 (2004) 43-47.

[13] Li Qingchun, The Properties of Bamboo Fiber and Key Technology in Development, Sichuan Textile Sci. Technol., 5 (2003) 56-58.

[14] Li Yan and Xu Hai-lin, Comparison of Serviceability of the Bamboo Fiber Fabric and the Ramie Fabric, J. Textile

Izvod

\section{FIZIOLOŠKE KARAKTERISTIKE ČARAPA OD BAMBUSOVIH I KONVENCIONALNIH VLAKANA}

Dušan S. Trajković ${ }^{\text {, Predrag S. Tasić }}{ }^{2}$, Jovan M. Stepanović1, Tatjana I. Šarac ${ }^{1}$, Nataša M. Radmanovac ${ }^{1}$

(ORIGINALNI NAUČNI RAD) UDK 677.072:687.254.8

1Univerzitet u Nišu, Tehnološki fakultet, Leskovac, Srbija

${ }^{2}$ Dunav AD, Grocka, Srbija

U radu su ispitivane fiziološke karakteristike čarapa proizvedenih od pređa sličnih fizičko-mehaničkih karakteristika ali različitog sirovinskog sastava (100 \% bambus pređa, $100 \%$ pamučna pređa, $100 \%$ viskozna pređa i pređa mešavine u odnosu $60 \%$ pamuk / 40 \% PES).

Rađene su čarape sa glatkim desno-levim 1:1 prepletajem i rebrastim 3:1 desno-levim prepletajem. U oba prepletaja čarape od bambusove pređe pokazale su znatno bolje fiziološke karakteristike u odnosu na one koje su izrađene od pređa iz konvencionalnih vlakana. Pletenine od bambusovih pređa, zbog mikro pukotina u strukturi vlakana, imaju mnogo bolje upijanje vlage a ujedno dobro održavanje osećaja toplote i odličnu prozračnost, što doprinosi osećaju svežine i opuštenosti, posebno u letnjim uslovima.

Sve ovo ukazuje da će se u budućnosti, zbog osobina koje poseduju, bambus vlakna i pređa izrađena od istih sve više koristiti u tekstilnoj industriji.
Keywords: fiziološke karakteristike, bambus pređa, čarape, pletenina. 